\section{DELAYED CLOSURE OF COMPOUND FRACTURE WOUNDS}

\author{
By ERIC W. Bintcliffe, M.S., F.R.C.S. \\ (Ronkswood Hospital, Worcester.)
}

\section{Introduction}

The treatment of infected compound fractures is a matter of compelling interest to all Orthopaedic Surgeons, and to those of us. who have seen and are still seeing the late results of such fractures of the first World War, the modern treatment of this type of injury is of special significance.

One continues to see, though necessarily, in diminishing numbers, "flares" with abscess formation followed by discharging sinuses with or without sequestra, resulting from infected compound fractures sustained in the last war, and although they frequently clear up temporarily, the period of invalidism may last weeks or even months, and, in fact, the state of ill-health tends to recur at shorter intervals, and to last longer as the patient gets older, and his general resistance to infection is lowered. Eventually, the patient. becomes incapacitated or undergoes amputation. Even, however, if he escapes the Scylla of permanent invalidism or the Charybdis of amputation, his life is punctuated at uncertain intervals by such periods of ill-health that one feels that in many cases, especially those involving the lower limb, amputation would have been the more humane, efficient, and certainly the more economic treatment.

The present war with its extreme degree of mechanisation in all branches of the Service, has inevitably produced, and, of course, is still producing large numbers of compound fractures, as a result of pure mechanical accidents, as distinct from battle casualties, and the terrific velocity of modern missiles together with their enormous explosive power, unite in producing fractures of a severity probably never before witnessed in the history of mankind. Therefore, if we are to avoid the indifferent and bad results of our previous treatment of such cases in the last war, it is certain that we must either prevent infection or eradicate it at the earliest possible moment.

Modern chemo-therapeutics of the sulphanilamide and other groups with the recent addition of penicillin have placed in our hands weapons with a power to overcome infection that can hardly be over-estimated. Recent work using penicillin in considerable dosage has shown that it is disappointing in chronic bone infections, largely because many organisms, even if of the penicillin sensitive variety are ensconced in sequestra or in dense fibrous tissue and so are inaccessible to it, whether it be administered locally or systemically. (I) Similar results in such cases have also been obtained with the sulphonamide group of chemotherapeutics, and therefore it is clear that if we are to improve our end results, treatment must aim at $(a)$ prevention of infection or $(b)$ eradication of the infection at the earliest opportunity. Certain factors, such as the soil of the battle field, the circumstances of the wounding, and the time before treatment is available are beyond our control, owing to the exigencies of modern war. Once, however, the patient is picked up prompt surgical treatment is available, comparatively quickly. This consists of debridement of the wound, adequate drainage by incision of deep fascia, and removal of damaged muscle and immobilisation of the fracture. Local and systemic chemotherapy is then instituted. The importance of conserving the skin excising only the minimum necessary and avoiding cruciate incisions at this early stage cannot be overemphasised in view of the subsequent desire to convert the compound fracture into a simple one by the suture of the wound.

Working at an advanced Base Hospital in the United Kingdom serving the French front, casualities were received usually at four-dayo intervals in convoys numbering up to 200 at a time.

In the early days of the campaign cases were evacuated by sea, and received their early treatment aboard a landing craft or hospital ship Those of us who were receiving these cases at the base were full of admiration for the quality of the work done aboard these vessels, as it must have been done under conditions of great difficulty. Other cases were treated at C.C.S.'s on arrival in England. Later on as airfields were established, a large proportion of the casualties returned in transport planes. Most of these had been treated in field hospitals in France and were then passed through a reception hospital before transfer to the base here. This complex organisation, which even went to the refinement of systemic penicillin therapy during transit, worked very smoothly, with the result that cases were received from I2 hours to several days from the time of wounding. The average time being four to five days.

\section{Treatment}

The seriously wounded, and most of the present series come into that category, were found on arrival to be in the middle of a systemic course of penicillin. This was continued, the aim being to give every serious compound fracture a seven days' course at least. The method of administration was by intramuscular injection at three- 
ILLUSTRATIONS ON

DELAYED CLOSURE OF COMPOUNI)

FRACTURE WOUNDS

by

ERIC W. BINTCLIFFE, M.S., F.R.C.S.

CASE 1
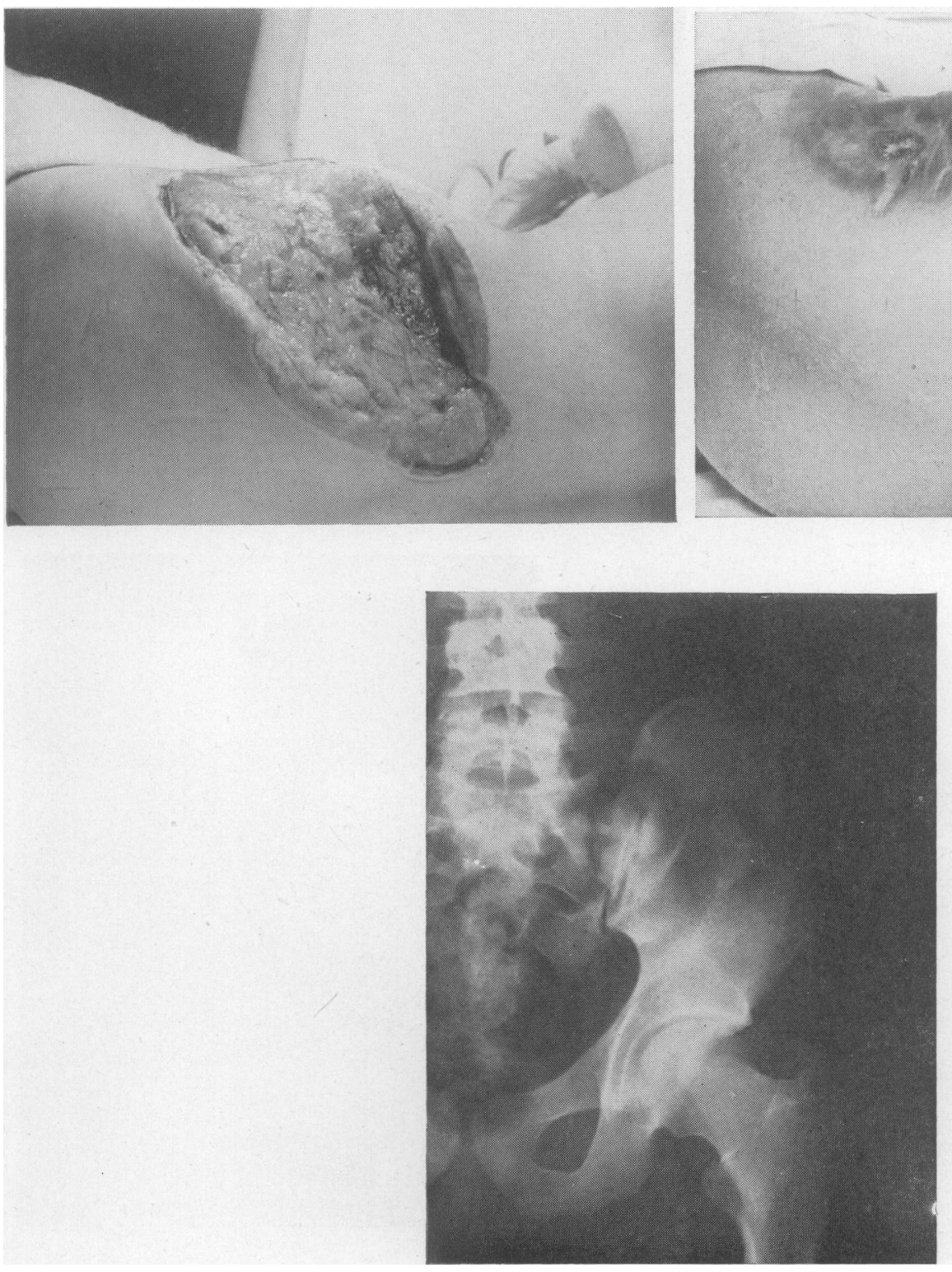
CASE 2
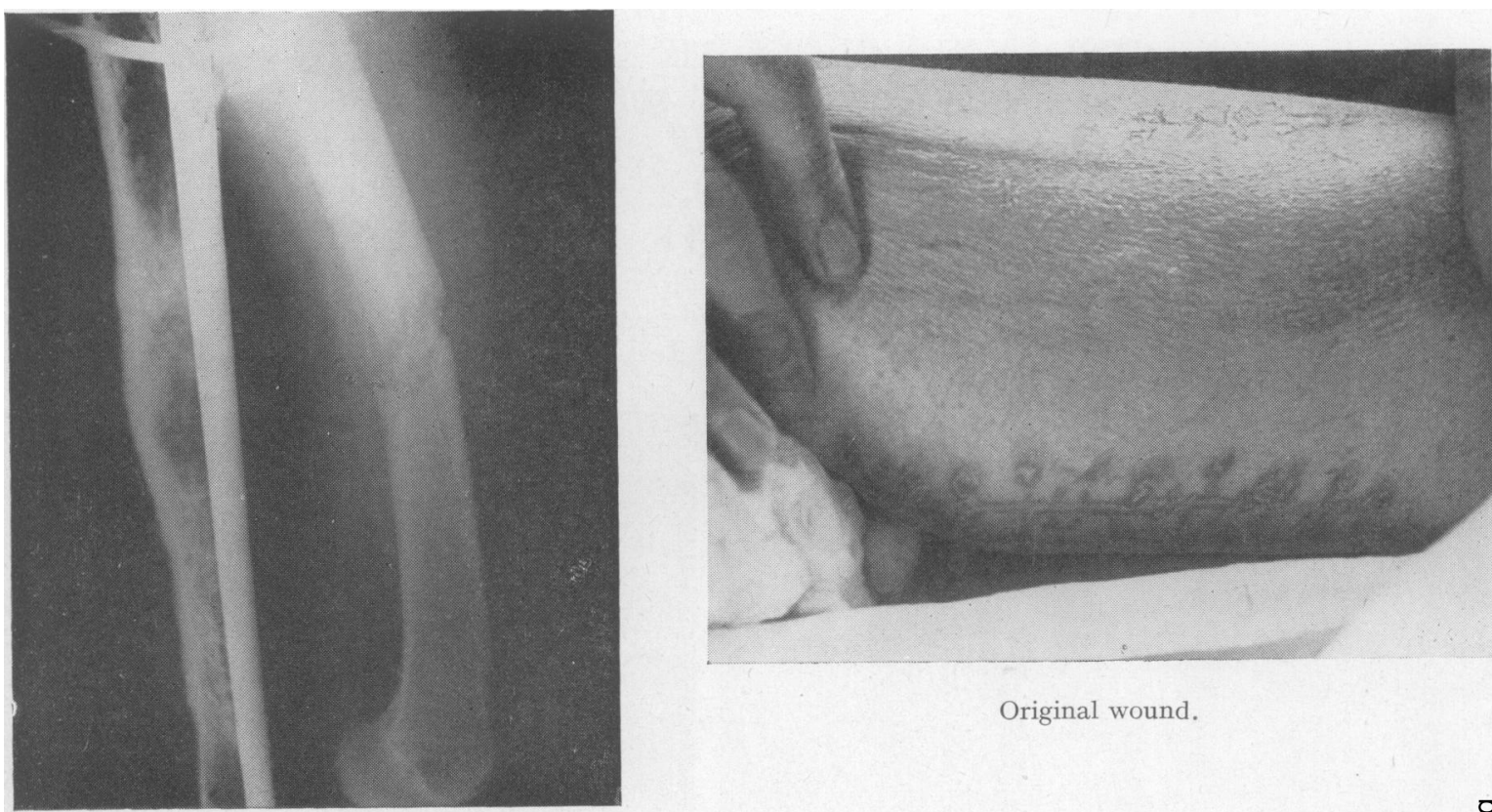

Original wound.
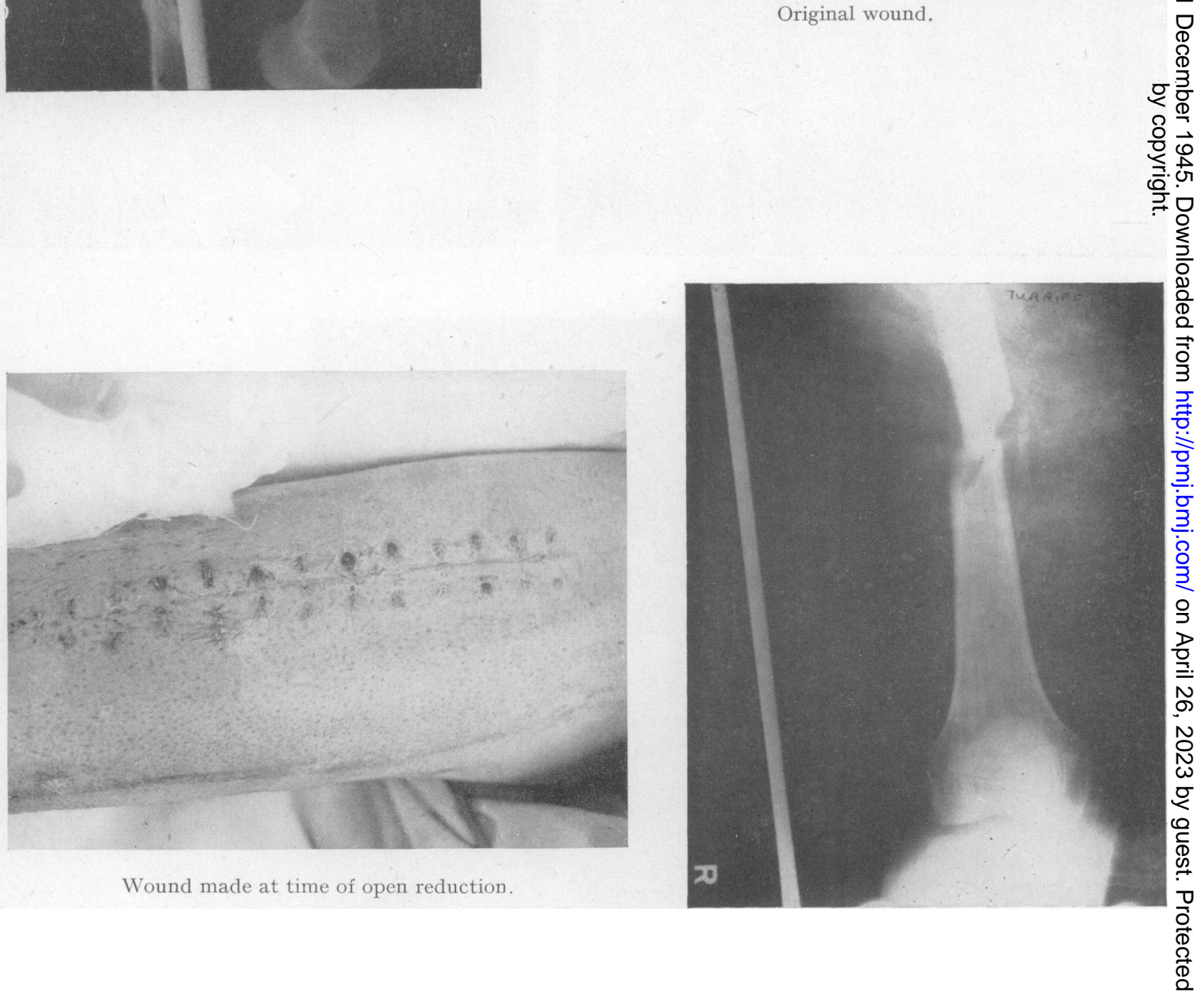

Wound made at time of open reduction. 
C.ASE 7
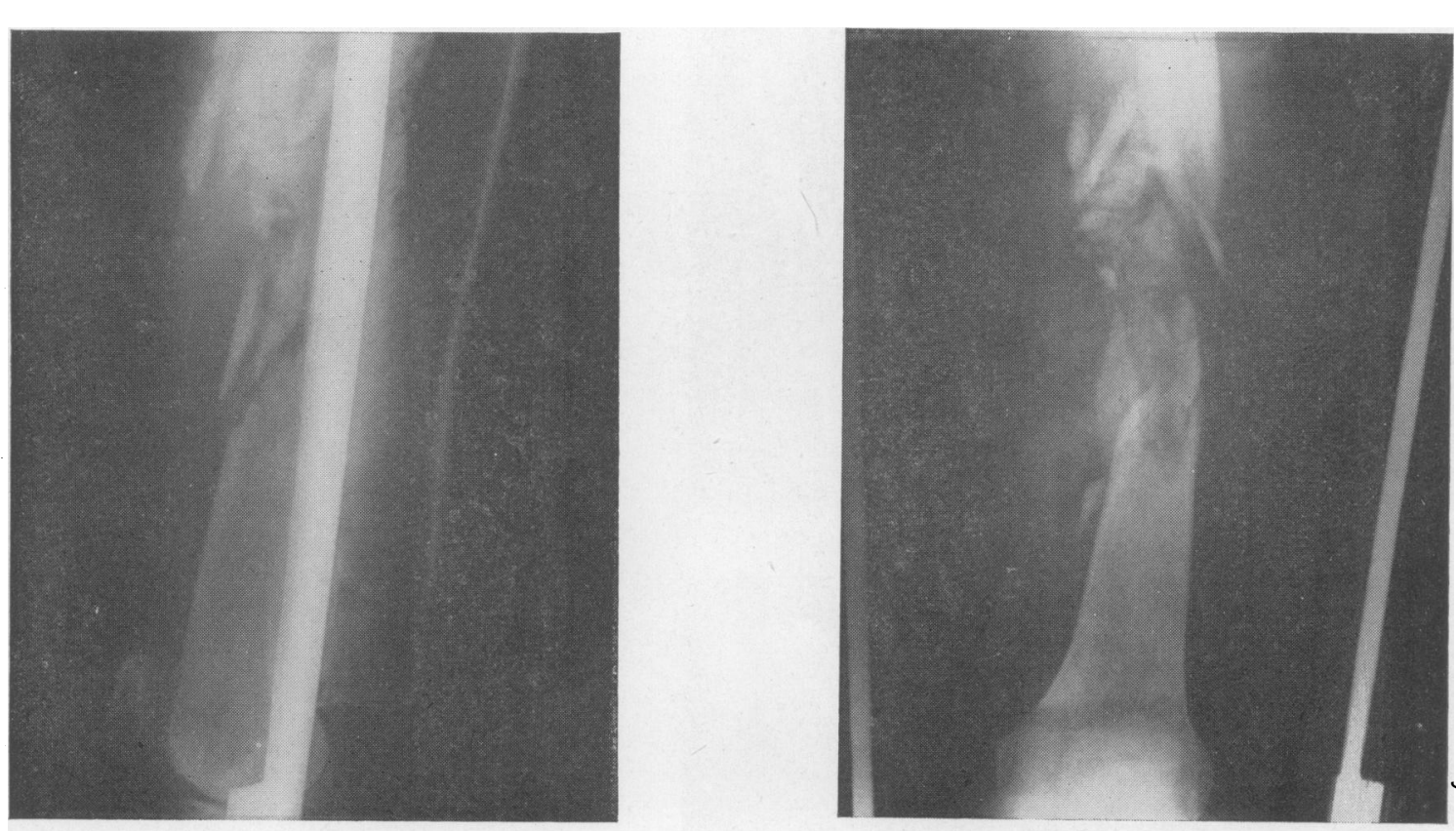


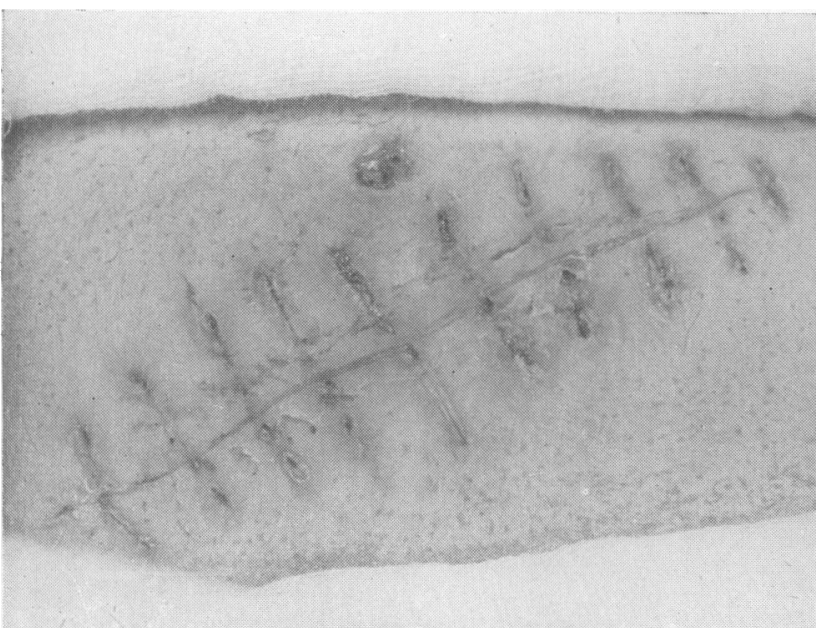

Ist wound inner side leg.

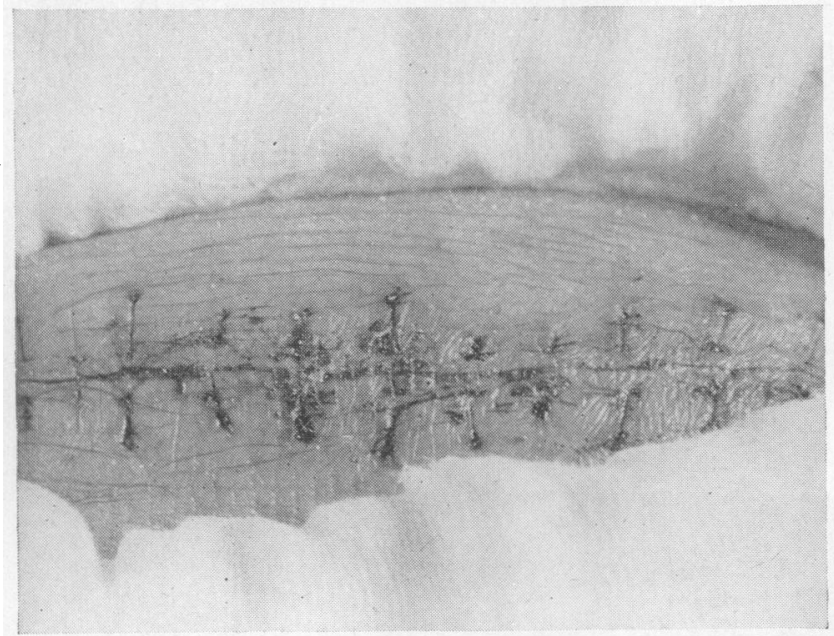

2nd wound outer side leg.

COMPOUND FRACTURE WOUNDS

E. W. BINTCLIFFE, M.S., F.R.C.S. $\frac{\stackrel{0}{0}}{\stackrel{0}{0}}$

CASE 26
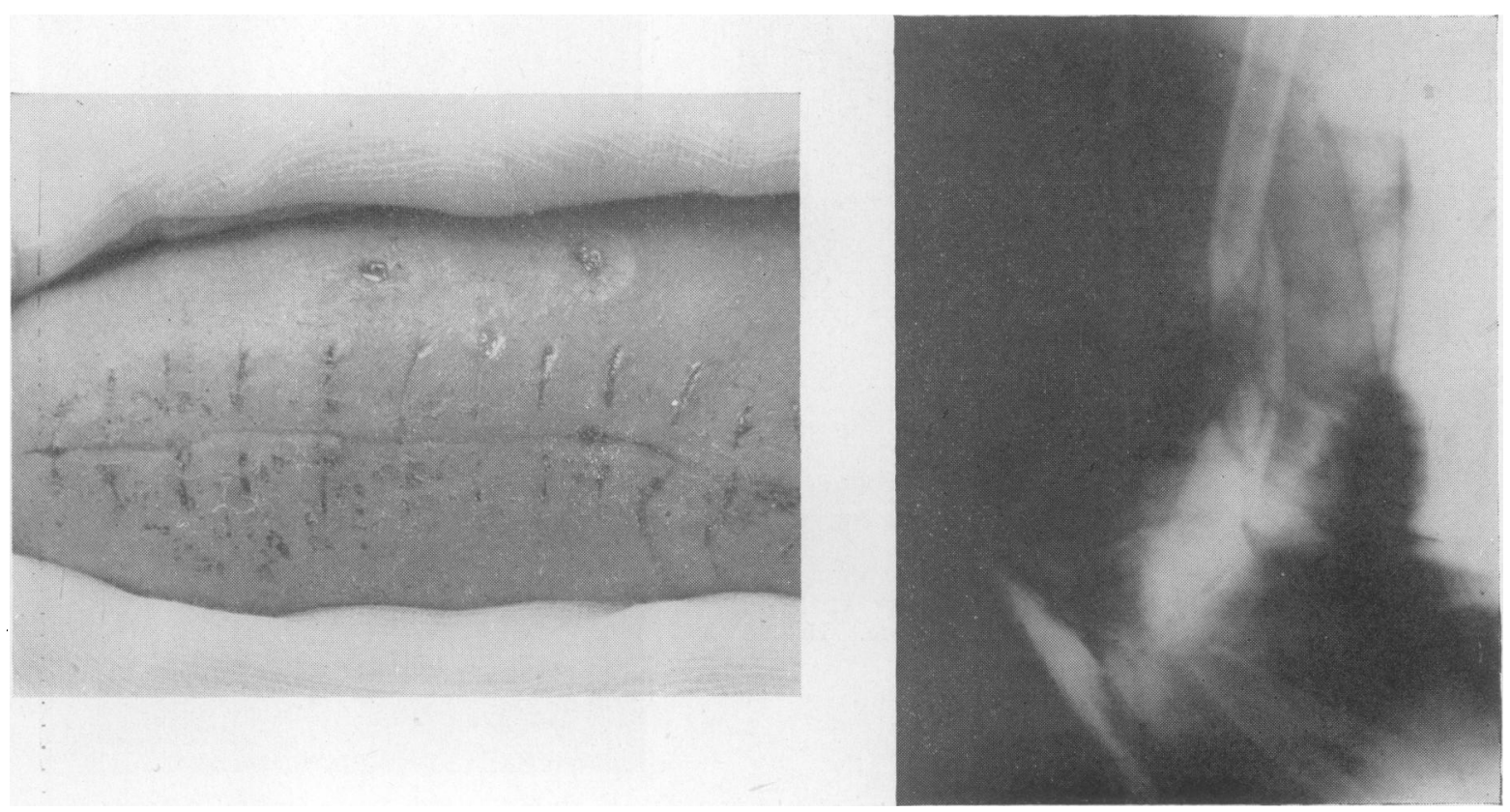

Case 30

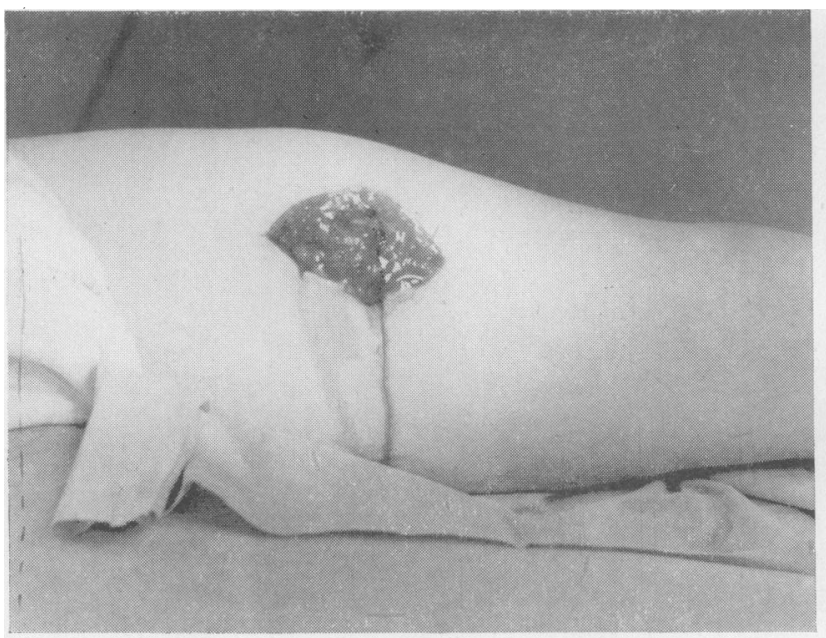

Compound fracture Femur. Exit wound.

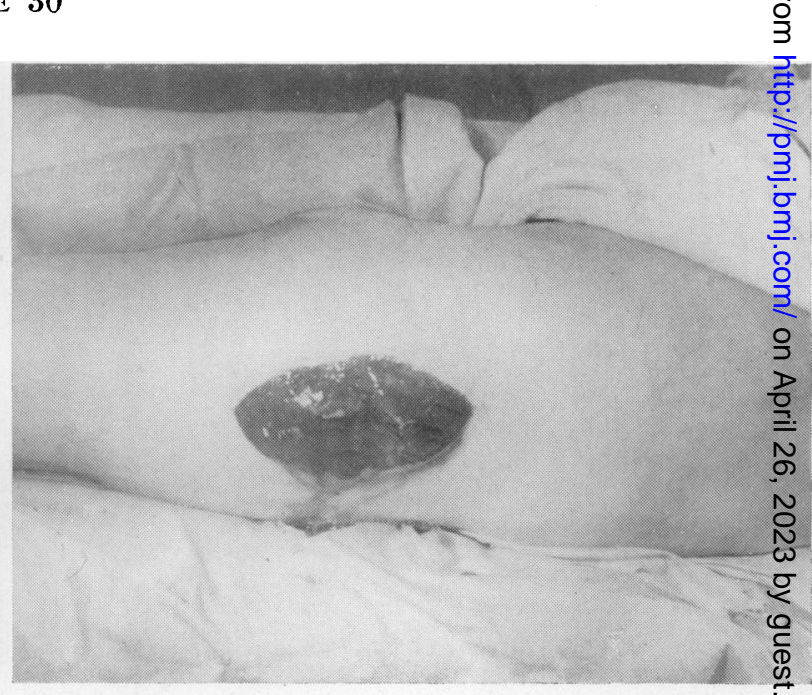

Compound fracture Femur. Entry wound. 

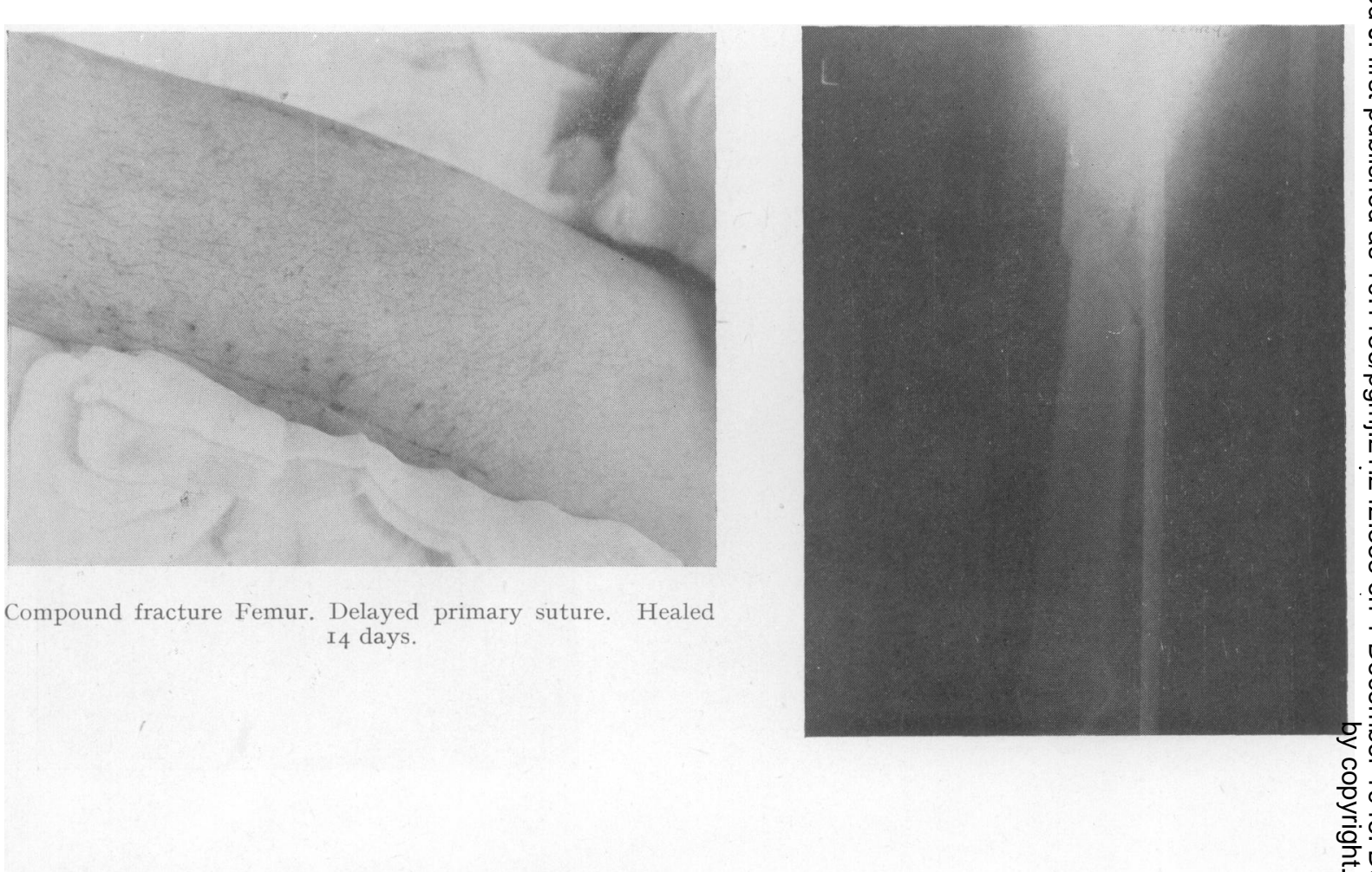

Compound fracture Femur. Delayed primary suture. Healed I4 days.
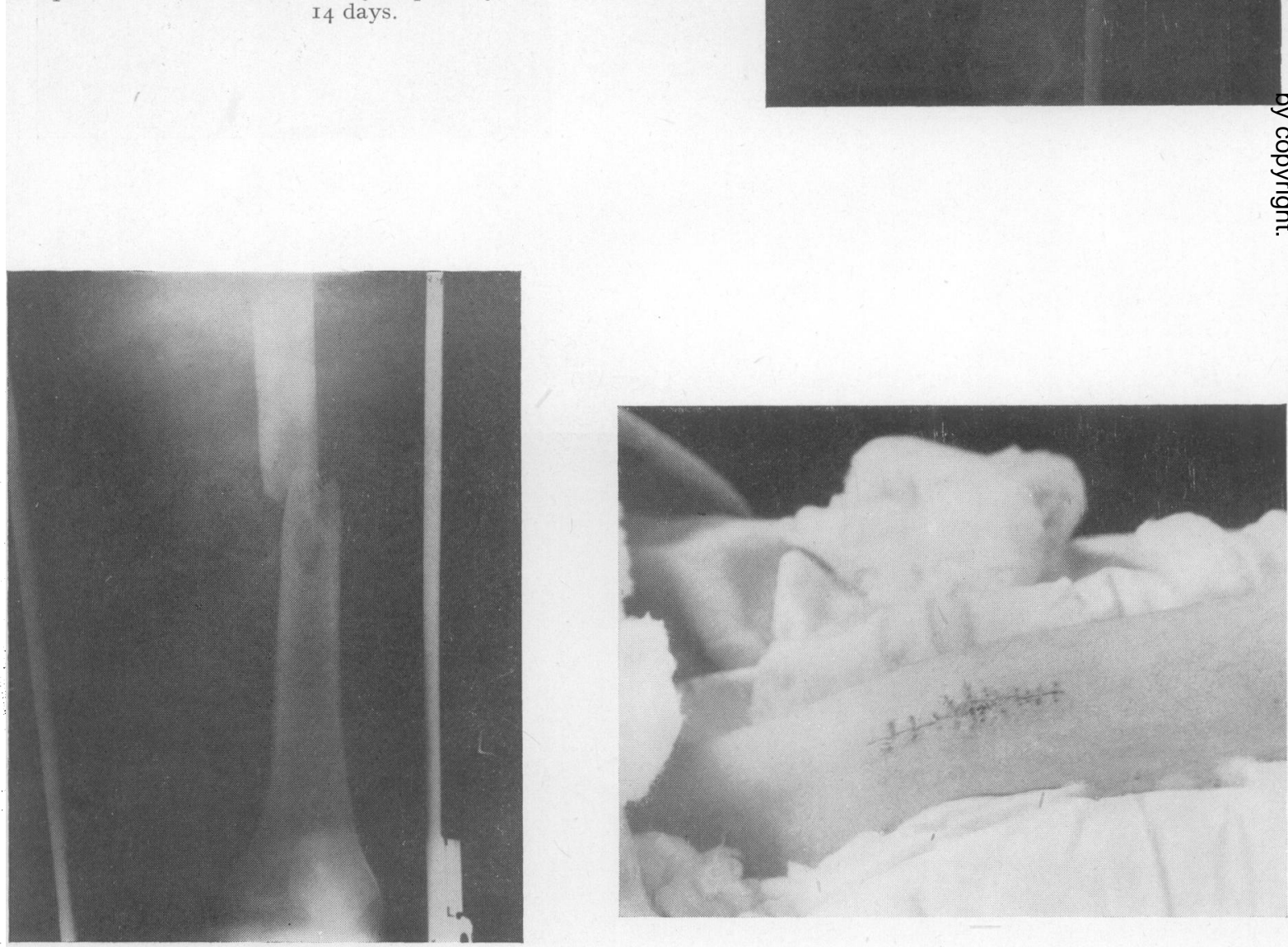
I4 days. 
hourly intervals, but later when the apparatus became available the continuous intramuscular drip was used. The dosage employed was moderate being 100,000 units in 24 hours. This amount is perhaps too small for intermittent injection to maintain a continuous adequate blood penicillin level, but it is adequate when given by continuous drip. (2)

The considerable variation in dosage shown on the chart of the cases treated was due to the very varying amounts given during transit as it not being possible to give injections at regular intervals, larger doses, in some cases as large as 90,000 units, were given at a time. Almost all patients had had one of the sulphonamide group of drugs, this also was continued until a $36 \mathrm{gm}$. course had been given, sulphamezathine being the preparation usually employed. Early treatment demands immobilisation rather than reduction, and providing the position is approximately correct refinements of reduction are not of such importance at this stage. Yet despite the fact that many of the fractures had been put up at advanced units bv clinical judgment alone, and without X-ray control, the majority were found to be in excellent position, and practically all had been satisfactorily immobilised.

The method of immobilisation generally adopted was the split padded plaster cast in most cases, and this proved satisfactory, although for femurs the Tobruk plaster was excellent. For severe fractures of the humerus and shoulder joint, the modified shoulder spica, or thoraco-brachial box, as it has come to be known, enabled the patients to travel comfortably and yet to be reasonably easily handled during transit.

Most men were in surprisingly good condition on arrival, but there were some with a low haemoglobin level. These were raised by transfusions before any further operative treatment was undertaken. A haemoglobin level above 70 per cent being desirable before further operation.

The aim of treatment was to convert as many as possible of the compound fractures into simple fractures at the earliest opportunity. Two main factors determined whether or not this could be accomplished. (I) The presence of infection in the wound. (2) The extent of the skin loss. An $\mathrm{X}$-ray to determine the position of the fracture was taken, then the immobilising plaster and dressings were removed in the operating theatre. This was done as soon after admission as possible, whilst the patient was still having a systemic course of penicillin. Care was taken not to displace the fracture further. The limb was cleaned with C.T.A.B. (cetyltrimethylamnoniumbromide) before removal of the inner dressings. A swab for bacteriological examination was taken, and then the wound itself, after draping with sterile towels, was carefully cleaned with the same solution. Any foreign bodies, pieces of clothing, dead tissue, or completely detached portions of bone which had not previously been dealt with were then removed, and a meticulous inspection of all parts of the wound was made. The decision whether or not to close the wound was, however, made on clinical appearances only, and the bacteriological findings utilised as a guide to further treatment, with especial regard to the presence of organisms sensitive to penicillin. Skin loss was the other important factor and often determined whether or not closure was technically possible. It was found to be inadvisable to close wounds under much tension as breakdown often occurred later.

Moderate tension was, however, permissible because when infection is controlled with penicillin oedema rapidly subsides and a wound which appears to be unduly "tight" is later found to have healed without any gaping of the edges.

An invariable cause of failure is suture of the skin over a cavity in the soft tissues or "tentage." In these cases suture should not be performed unless the underlying soft tissue defect can also be closed, otherwise breakdown will occur, and a sinus result. In some cases a rotation flap or counter incision will allow closure of the wound. Any secondary defect thus created being treated by skin grafting. In other cases suture of the portion of the wound in immediate communication with the fracture was possible at the expense of leaving a raw area at some other unimportant part of the wound, this area being grafted. In all cases complete closure of the wound was aimed at by "delayed primary suture," the optimum time for this being the $5^{\text {th }}$ to Ioth day after wounding. In the cases to be described the interval between wounding and suture varies considerably, this is due to the different times after wounding at which patients were received back at the base. In the older cases in which the skin edges had become fixed a "secondary suture" with re-excision of the wound and undercutting of the skin edges was required. The wounds were sutured with interrupted silk sutures of the everting mattress type to give accurate skin approximation. In some cases a fine rubber tube of the Carrell Dakin type with lateral holes was placed down to the sight of fracture and brought out through a separate stab incision or through one extremity of the sutured wound. If the wound was large two tubes were used. In smaller wounds not suitable for the use of a penicillin tube for irrigation purposes penicillin powder (5,000 units per gm.) was insufflated with the R.A.F. type insufflator prior to suture. In other cases proflavine sulphathiozole powder (I per cent proflavine 99 per cent sulphiolzole) was 
used in the same way. The wound was then dressed and a tube if present brought out through the dressing. The fracture was then reduced, accurate reduction intended to be the final result being aimed at. Fractures of the femur were treated by orthodox methods on a Thomas splint with skeletal traction by means of a Kirshner wire through the tibial tuberosity. It was found that better control of the fracture could be obtained by making a moulded plaster gutter on the upper part of the Thomas splint for the thigh to rest on as far as the knee joint. This was covered with a layer of Gamgee tissue, and suitable pads of the same material could be placed where necessary under the limb to maintain the correct bowing of the femur. This arrangement obviated the frequent adjustments necessary with the ordinary bandage type of slings and clips, and was found to be a great saving of labour when a considerable number of femoral fractures were under treatment. A Pearson knee flexion piece was fitted about four weeks after reduction to allow knee movement. The plaster hip spica was employed for fractures of the upper end of the femur, and those involving the hip joint. A double spica incorporating the sound leg as far as the knee was employed so as to obtain satisfactory immobilisation of the pelvis. All such casts were carefully padded with felt and accurately moulded to the contours of the body. A wooden strut was placed between the legs for additional rigidity. This small point is important as patients in hip spicas should be turned several times a day and broken casts are to be avoided. The plaster spica was also found to be very useful for much comminuted fractures of the femur whatever their situation. These fractures are difficult to control on a Thomas splint, and distraction takes place all too readily with resulting delay in union. Having tried both methods, the spica is now preferred for this type of fracture. For shoulder joint and humerus fractures the ordinary plaster shoulder spica was used with a suitable degree of abduction of the arm when necessary. Quite a few of the cases of compound fractured humerus were found to have a musculo spiral nerve palsy. A banjo type splint with two wire hoops placed at right angles to each other was fitted to the thoraco-brachial spica in these patients. An extension was taken from the finger nail by means of a thread stitch through the extremity of the nail and fixed with an elastic band to one loop of the splint. A small webbing sling was placed under the proximal inter-phalyngeal joint of each finger and attached by elastic to the dorsal hoop of the splint. In this way the hand can be maintained in the position of function and exercised against elastic resistance. Some humeral fractures were treated by the "hanging cast" method. Tibial fractures that required extension were reduced by means of a Kirshner $\frac{a}{3}$ wire through the lower end of the tibia and extension on a Bohler's frame followed by immo- $c$ bilisation in a full-length plaster cast. The knee being flexed about 35 degrees and the cast was $\stackrel{\vec{F}}{\longrightarrow}$ then placed on a Brawn's splint. The Kirshnero wire was incorporated in the plaster. Two months later the cast was removed and usually the fracture $\frac{\overline{0}}{5}$ showed sufficient union for a walking cast to be $\stackrel{\mathbb{\Omega}}{\varrho}$ applied with the knee fully extended. The Kirshner wire was of course removed, but if union क was found to be absent the wire was useful for? maintaining correct alignment during the applica- $\overrightarrow{\vec{\omega}}$ tion of the second cast after which it was removed. Difficult tibial fractures were reduced by the 8 double pin method using the Zimmer reduction 3 apparatus, and this was found to be very successful, is but distraction should be avoided. A fine gauge $\vec{i}$ wire was always used and no trouble was ex- $\vec{N}$ perienced with infection of the pin tracts, but great care was taken to avoid placing them too close to $\infty$ an infected wound. Plaster casts were not split $ᄋ$ and the minimum of padding was used, this being applied over pressure points. The casts were carefully moulded to ensure an accurate fit. (One $\underset{\varnothing}{\varnothing}$ or two cases which had been accurately reduced $\stackrel{\mathbb{S}}{3}$ before admission to this hospital were transferred to Auxiliary hospitals in their original paddes plasters. As the swelling subsided and the wo inside the cast became compressed the fracture. of became displaced. This occurrence caused us make a habit of changing all such plasters.)

The penicillin tubes were allowed to project through the plaster casts and introduction of penicillin solution 250 units per c.c. was done at $\mathbb{D}$ I2-hourly intervals usually for a period of five to $\overrightarrow{\vec{F}}$ seven days. The amount of solution used for any individual case depended on the size of the wound. Usually not less than 5 c.c. or more than ro c.c. per injection was used, except for very large wounds. Great care must be taken to ensure the sterility of the end of the penicillin tube as there is a risk of introducing gram-ve organisms. One 3 or two special methods have been described in the literature to prevent this occurring. At the end of fourteen days a window was cut in the plaster 0 cast over the wound and the penicillin tube and stitches removed. The state of the healing of the wound was then noted.

\section{Results}

The results were classified into three main groups:-

A. Good.-i.e. Clean healing of the wounds in I4 days and no bone necrosis. 
B. Satisfactory.-i.e. Wounds healed, but with some delay usually due to Gram-ve pus, no bone necrosis present.

C. Failure.-i.e. Those in which the secondarily sutured wound broke down followed by bone necrosis and sequestrum formation.

These results are shown in Table 2, which indicates that there were $\mathrm{I} 7$ or 57 per cent of good results, 9 or 30 per cent of satisfactory results, and 4 or 13 per cent of failures.

\section{Table 2}

\begin{tabular}{lrrrr} 
Result & \multicolumn{3}{c}{ Number of Cases } & $\%$ \\
Good &. & $\ldots$ & I7 & 57 \\
Satisfactory &. & $\ldots$ & 9 & 30 \\
Failure &.. & $\ldots$ & 4 & I3
\end{tabular}

The complete analysis of the cases is given in Table I. This shows the type of fracture, the size and appearance of the wound at the time of closure, the bacteriology of the wound, the number of days elapsing between infliction of the wound and closure, details of penicillin therapy both systemic and local, details of other chemotherapeutic agents such as sulphonamides, the condition of the wound with regard to healing I4 days after suture, and any special remarks in relation to each particular case. The last column gives the results previously mentioned classified into Good, Satisfactory, or Failure. A reproduction of the X-ray of each case together with a photograph of the wound is included, although for obvious reasons of paper restrictions it is only possible to reproduce a few of these X-rays and photographs. Most of the X-ray plates show the position of the fracture after reduction. It is regretted that facilities at the time this work was done did not permit a photographic record to be made in the operating theatre of the original wound. The work was done when the hospital was operating under extremely heavy pressure, some 3,000 casualties being treated in the course of four months, and I must apologise therefore for the clinical data being incomplete in some instances. A much larger series of cases might have been presented had more staff been available. It was found to be possible to close the wounds in the majority of the compound fractures treated and the thirty cases chosen at random are presented here as an example. A few points of interest arise from a consideration of some of the cases. Case No. 2 healed in spite of the presence in the wound of B. Proteus, but 20 days after closure of the wound an open reduction of the fracture was performed as all other methods had failed to secure satisfactory alignment, and when the fracture site was exposed fluid resembling pus was encountered. It was feared that suppuration would follow the operation, but the fracture was manipulated into good position under vision and the wound closed, no foreign bodies such as a plate or screws being introduced, and healing was perfect.

The formation of Gram-ve pus due to infection with B. Proteus and Ps. Pyocyaneus is a problem of increasing magnitude, and in this small series it occurred in no less than 7 cases in which it spoiled the good result which might have been obtained. The wounds in these cases, Nos. 2, 6, 9 , I2, I3, I6, 24, either failed to heal or more frequently healed and then broke down again. Fortunately, in most cases healing was only delayed and bone necrosis due to this infection did not often occur. Some of these cases may have become infected via the penicillin tube and the danger of this has already been mentioned. This is a strong argument in favour of systemic administration, but local penicillin has its uses for the sterilisation of avascular tissue, should this be present in the wound, and a much higher local concentration is possible at the fracture site than by any other method. B. Coli was present in six cases and in all but two of these closure of the wound failed. It is noteworthy that in the two wounds infected with this organism which were successfully closed proflavine sulphathiozole powder was used. This preparation seems to have a definite value in controlling infection with the Gram-ve bacteria. Penicillin by eliminating the Gram-ve cocci seems in some cases to favour, if not actually encourage, the growth of the gram-ve group of organisms and this often seems to occur at seven to ten days by which time penicillin has eliminated staphylococci and streptococci. It was unfortunate that at the time this work was undertaken ethyleneglycolmomophenylether "phenoxetol" which has been shown to have a definite action on Ps. Pyocyaneus was not available.(3) It has since become available, however, and is now being used in the treatment of these cases. Preliminary trials with this drug suggest that it can produce definite reduction in Ps. Pyocyaneus infection, but that the organism is not completely eliminated and recurrence takes place when the drug is discontinued. The absence of streptococci is a noteworthy feature. The haemolytic streptococcus was found in one case only, No. 7, and in two other cases, Nos. I5, I9, non-haemolytic streptococci were isolated. The probable reason for the almost complete elimination of this organism, so common in the last war, is the use of the sulphonamides and penicillin. Organisms of the Clostridia group are not found in this series. As previously mentioned wound closure was per- 
TABLE

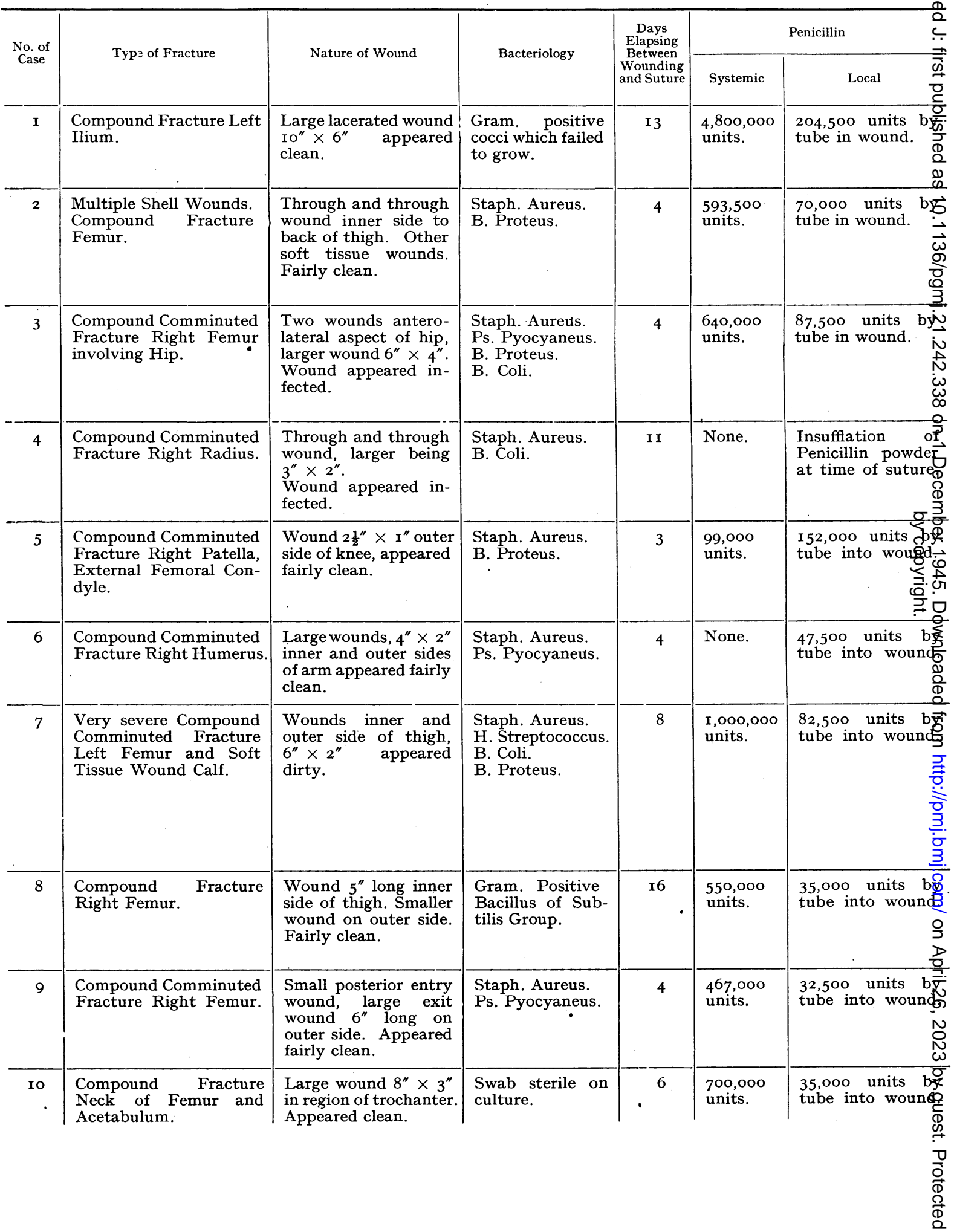




\begin{tabular}{|c|c|c|c|}
\hline Chemo-Therapeutic Agents & $\begin{array}{l}\text { Condition of Wound } \\
\text { I4 Days after Suture }\end{array}$ & Comments & Result \\
\hline Course of Sulphadiazine. & $\begin{array}{l}\text { Healed and stitches re- } \\
\text { moved. }\end{array}$ & $\begin{array}{l}\text { Wide wound sutured except small area in front. } \\
\text { Healing with minimum formation of Gram. } \\
\text { negative pus. } \\
\text { No bone necrosis. }\end{array}$ & Good. \\
\hline $\begin{array}{l}\text { Course of Sulphanilamide. } \\
\text { Prophylactic Anti-Gas Serum. }\end{array}$ & $\begin{array}{l}\text { Wound healed and } \\
\text { stitches removed. }\end{array}$ & $\begin{array}{l}\text { Slight Gram. negative pus. Open reduction of } \\
\text { fracture because of unsatisfactory position per- } \\
\text { formed } 9.8 .44 \text {, i.e. } 20 \text { days after suture. Wound } \\
\text { healed and original wounds did not break } \\
\text { down. } \\
\text { No bone necrosis. }\end{array}$ & Good. \\
\hline $\begin{array}{l}\text { Sulphanilamideapplied to wound } \\
\text { at time of first excision. } \\
\text { Course of Sulphamezathine. } \\
\text { Proflavine Sulphathiazole pow- } \\
\text { der insufflated into wound at } \\
\text { time of suture. }\end{array}$ & $\begin{array}{l}\text { Complete healing of } \\
\text { one wound, partial } \\
\text { healing of the larger } \\
\text { wound with consider- } \\
\text { able Gram. negative } \\
\text { pus. }\end{array}$ & $\begin{array}{l}\text { Good result spoiled by Gram. negative pus. } \\
\text { The smaller of the two wounds healed cleanly. } \\
\text { The larger anterior wound was not healed } \\
\text { until I4.9.44. } \\
\text { No bone necrosis. }\end{array}$ & $\begin{array}{l}\text { Satis- } \\
\text { factory. }\end{array}$ \\
\hline Course of Sulphamezathine. & $\begin{array}{l}\text { Wounds healed when } \\
\text { plaster removed. A } \\
\text { window was not cut in } \\
\text { this case. }\end{array}$ & $\begin{array}{l}\text { Clean healing had taken place as there was no } \\
\text { discharge inside the plaster when it was } \\
\text { removed. Presence of B. Coli did not prevent } \\
\text { healing in this case. } \\
\text { No bone necrosis. }\end{array}$ & Good. \\
\hline $\begin{array}{l}\text { Course of Sulphamezathine. } \\
\text { Prophylactic Anti-Gas Serum. }\end{array}$ & Wound nearly healed. & $\begin{array}{l}\text { Slight amount of Gram. negative pus at i4th } \\
\text { day when stitches were removed. Healing } \\
\text { progressed and when plaster was finally re- } \\
\text { moved wound was soundly healed. } \\
\text { No bone necrosis. }\end{array}$ & Good. \\
\hline Course of Sulphamezathine. & Wound partly healed. & $\begin{array}{l}\text { Healing impaired by Gram. negative pus. } \\
\text { No bone necrosis. }\end{array}$ & $\begin{array}{l}\text { Satis- } \\
\text { factory. }\end{array}$ \\
\hline $\begin{array}{l}\text { Course of Sulphamezathine. } \\
\text { Prophylactic Anti-Gas Serum. }\end{array}$ & $\begin{array}{l}\text { Wound on inner side } \\
\text { healed. Wound on } \\
\text { outer side broke down. }\end{array}$ & $\begin{array}{l}\text { Inner wound successful closure. Outer wound } \\
\text { a complete failure and it would have been } \\
\text { better not to have tried suture. Failure due to } \\
\text { massive infection and longer interval between } \\
\text { wounding and suture. } \\
\text { Bone necrosis developed and sequestreotomy } \\
\text { was required on } 7 \cdot 9.44 . \\
\text { Extensive soft tissue calf wound also } \\
\text { present. }\end{array}$ & Failure. \\
\hline Course of Sulphanilamide. & $\begin{array}{l}\text { Both wounds com- } \\
\text { pletely healed. }\end{array}$ & $\begin{array}{l}\text { Complete healing of both wounds. No Gram. } \\
\text { negative pus. } \\
\text { Patient also had extensive burns of hands } \\
\text { arms, and face. } \\
\text { No bone necrosis. }\end{array}$ & Good. \\
\hline Course of Sulphathiazole. & $\begin{array}{l}\text { Posterior wound healed. } \\
\text { Lateral wound healed } \\
\text { in upper part. }\end{array}$ & $\begin{array}{l}\text { Complete healing prevented by presence of } \\
\text { Gram. negative pus in lateral wound. This } \\
\text { delayed healing, but no bone necrosis developed. }\end{array}$ & $\begin{array}{l}\text { Satis- } \\
\text { factory }\end{array}$ \\
\hline Course of Sulphamezathine. & $\begin{array}{l}\text { Wound completely } \\
\text { healed and stitches re- } \\
\text { moved. }\end{array}$ & $\begin{array}{l}\text { Complete healing of wound not spoiled by } \\
\text { Gram. negative pus. } \\
\text { No bone necrosis. }\end{array}$ & $\begin{array}{l}\text { Good. } \\
\text { ontinued }\end{array}$ \\
\hline
\end{tabular}


TABLE $\stackrel{0}{\stackrel{0}{\Phi}}$

\begin{tabular}{|c|c|c|c|c|c|c|}
\hline \multirow{2}{*}{$\begin{array}{l}\text { No. of } \\
\text { Case }\end{array}$} & \multirow{2}{*}{ Type of Fracture } & \multirow{2}{*}{ Nature of Wound } & \multirow{2}{*}{ Bacteriology } & \multirow{2}{*}{\begin{tabular}{|c|} 
Days \\
Elapsing \\
Between \\
Wounding \\
and Suture
\end{tabular}} & \multicolumn{2}{|r|}{ Penicillin } \\
\hline & & & & & Systemic & Local \\
\hline II & $\begin{array}{l}\text { Compound Comminuted } \\
\text { Fracture Right Radius. }\end{array}$ & $\begin{array}{l}\text { Small wound } 2 \frac{1}{2}^{\prime \prime} \\
\text { Appeared clean. }\end{array}$ & Not available. & 15 & $\begin{array}{l}230,000 \\
\text { units. }\end{array}$ & $\begin{array}{l}\text { Insufflation of } \\
\text { Penicillin powdes } \\
\text { at time of sutures }\end{array}$ \\
\hline 12 & $\begin{array}{l}\text { Compound Comminuted } \\
\text { Fracture Left Femur. }\end{array}$ & $\begin{array}{l}\text { Wound } 4^{\prime \prime} \text { long an- } \\
\text { terior aspect of thigh. }\end{array}$ & Staph. Aureus. & 8 & $\begin{array}{l}950,000 \\
\text { units. }\end{array}$ & $\begin{array}{l}137,500 \text { units by } \\
\text { tube into wound } \\
\\
\frac{\vec{\omega}}{\omega}\end{array}$ \\
\hline I3 & $\begin{array}{l}\text { Compound, Severely } \\
\text { Comminuted Supracon- } \\
\text { dylar Fracture Right } \\
\text { Femur. }\end{array}$ & $\begin{array}{l}\text { Small posterior en- } \\
\text { trance wound, large } \\
5^{\prime \prime} \times 3^{\prime \prime} \text { lateral exit } \\
\text { wound. } \\
\text { Appeared fairly clean. }\end{array}$ & $\begin{array}{l}\text { Swab sterile on } \\
\text { culture. }\end{array}$ & 4 & $\begin{array}{l}860,000 \\
\text { units. }\end{array}$ & 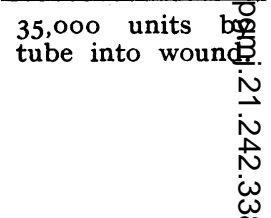 \\
\hline$I_{4}$ & $\begin{array}{l}\text { Severe Compound Com- } \\
\text { minuted Fracture Right } \\
\text { Tibia and Fibula. }\end{array}$ & $\begin{array}{l}\text { Small wound } 3 " \text { long } \\
\text { lower third of leg. } \\
\text { Appeared clean. }\end{array}$ & Not available. & $\mathbf{I}$ & $\begin{array}{l}\text { 70o,ooo } \\
\text { units. }\end{array}$ & $\begin{array}{l}\text { Insufflation } \\
\text { Penicillin powder } \\
\text { at time of suture. } \\
\end{array}$ \\
\hline 15 & $\begin{array}{l}\text { Compound Comminuted } \\
\text { Fracture Left Femur } \\
\text { involving Knee Joint. }\end{array}$ & $\begin{array}{l}\text { Wound } 4^{\prime \prime} \times 2^{\prime \prime} \text { an- } \\
\text { tero-lateral aspect of } \\
\text { thigh. } \\
\text { Appeared infected. }\end{array}$ & $\begin{array}{l}\text { Non-haemolytic } \\
\text { Streptococcus. } \\
\text { B. Proteus. } \\
\text { Ps. Pyocyaneus. }\end{array}$ & 7 & $\begin{array}{l}\text { 70o,ooo } \\
\text { units. }\end{array}$ & 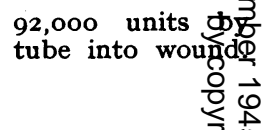 \\
\hline 16 & $\begin{array}{l}\text { Compound Comminuted } \\
\text { Fracture Femoral Con- } \\
\text { dyle. }\end{array}$ & $\begin{array}{l}\text { Wound } 3^{\prime \prime} \times I^{\prime \prime} \text { on } \\
\text { lateral side of knee. } \\
\text { Appeared infected. }\end{array}$ & $\begin{array}{l}\text { Staph. Albus. } \\
\text { Ps. Pyocyaneus. }\end{array}$ & 8 & $\begin{array}{l}\text { 48o,ooo } \\
\text { units. }\end{array}$ & $\begin{array}{l}\text { 135,00o units } 9 \text { 解 } \\
\text { tube into wound }\end{array}$ \\
\hline 17 & $\begin{array}{l}\text { Compound Comminuted } \\
\text { Fracture Left Femur. }\end{array}$ & $\begin{array}{l}\text { Large wound postero- } \\
\text { lateral aspect of thigh } \\
3 \frac{1}{2} \text { "long wound granu- } \\
\text { lating. }\end{array}$ & Not available. & 22 & $\begin{array}{l}680,000 \\
\text { units. }\end{array}$ & None. \\
\hline 18 & $\begin{array}{l}\text { Compound Fracture } \\
\text { Lower End Right } \\
\text { Femur, also Perforating } \\
\text { Abdominal Wound. }\end{array}$ & $\begin{array}{l}\text { Large wound } 4^{\prime \prime} \text { long } \\
\text { lateral side of thigh. } \\
\text { Appeared clean. }\end{array}$ & $\begin{array}{l}\text { Swab sterile on } \\
\text { culture. }\end{array}$ & 20 & $\begin{array}{l}\text { r,980,00o } \\
\text { units. }\end{array}$ & 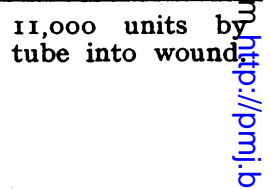 \\
\hline 19 & $\begin{array}{l}\text { Compound Comminuted } \\
\text { Fracture Left Humerus. }\end{array}$ & $\begin{array}{l}\text { Large lateral wound } \\
4^{\prime \prime} \times 2^{\prime \prime} \text {. Smaller } \\
\text { medial wound. Pus } \\
\text { present in wound. }\end{array}$ & $\begin{array}{l}\text { Staph. Aureus. } \\
\text { Non-haemolytic } \\
\text { Streptococcus. } \\
\text { B. Subtilis. }\end{array}$ & 3 & $\begin{array}{l}825,000 \\
\text { units. }\end{array}$ & $\begin{array}{l}4 \mathrm{I}, 250 \text { units b产. } \\
\text { tube into wound }\end{array}$ \\
\hline 20 & $\begin{array}{l}\text { Compound Fracture } \\
\text { Head of Femur, Ace- } \\
\text { tabulum. }\end{array}$ & $\begin{array}{l}\text { Large lateral wound } \\
4^{\prime \prime} \times 3^{\prime \prime} \text { over Left } \\
\text { Trochanter. } \\
\text { Appeared clean. }\end{array}$ & B. Coli. & 5 & $\begin{array}{l}\text { r, ro4,000 } \\
\text { units. }\end{array}$ & $\begin{array}{l}21,250 \text { units } \\
\text { tube into woundo }\end{array}$ \\
\hline $2 \mathbf{I}$ & $\begin{array}{ll}\text { Compound, } & \text { Severely } \\
\text { Comminuted } & \text { Fracture } \\
\text { Left Humerus. } & \end{array}$ & $\begin{array}{l}\text { Small posterior entry } \\
\text { wound, large exit } \\
\text { wound } 3^{\prime \prime} \times \mathrm{I}_{2}^{\prime \prime} \text { on } \\
\text { antero-lateral aspect } \\
\text { of shoulder. Fairly } \\
\text { clean. }\end{array}$ & $\begin{array}{l}\text { Staph. Aureus. } \\
\text { B. Coli. }\end{array}$ & 10 & $\begin{array}{l}\text { 70o,ooo } \\
\text { units. }\end{array}$ & 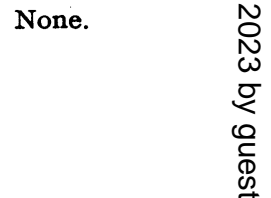 \\
\hline
\end{tabular}




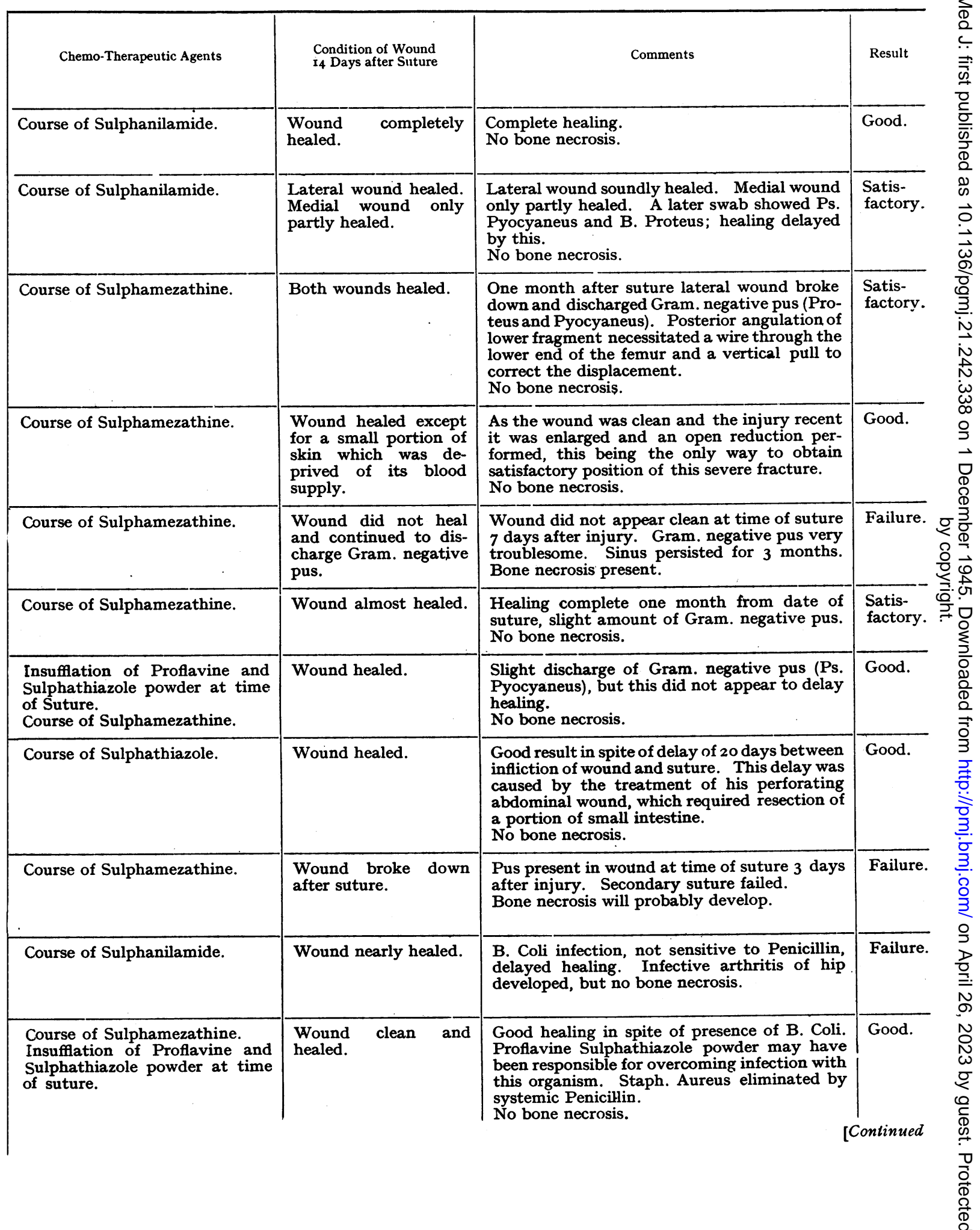




\begin{tabular}{|c|c|c|c|c|c|c|}
\hline \multirow{2}{*}{$\begin{array}{l}\text { No. of } \\
\text { Case }\end{array}$} & \multirow{2}{*}{ Type of Fracture } & \multirow{2}{*}{ Nature of Wound } & \multirow{2}{*}{ Bacteriology } & \multirow{2}{*}{$\begin{array}{l}\text { Days } \\
\text { Elapsing } \\
\text { Between } \\
\text { Wounding } \\
\text { and Suture }\end{array}$} & \multicolumn{2}{|r|}{ Penicillin } \\
\hline & & & & & Systemic & Local \\
\hline 22 & $\begin{array}{l}\text { Compound, Severely } \\
\text { Comminuted Fracture } \\
\text { Tibia and Fibula. }\end{array}$ & $\begin{array}{l}\text { Wound inner side } \\
3^{\prime \prime} \times \mathrm{I}_{\frac{1}{2}}^{\prime \prime} \text {, wound outer } \\
\text { side } 5^{\prime \prime} \text { long. Fairly } \\
\text { clean. }\end{array}$ & $\begin{array}{l}\text { Staph. Aureus. } \\
\text { B. Subtilis. }\end{array}$ & 5 & None. & $\begin{array}{l}\text { r4,500 units } \\
\text { tube into woung }\end{array}$ \\
\hline 23 & $\begin{array}{l}\text { Compound Fracture } \\
\text { Radius and Ulna. }\end{array}$ & $\begin{array}{l}\text { Wound } 2 \frac{1}{2}^{\prime \prime} \times I^{\prime \prime} \text { inner } \\
\text { side of forearm. } \\
\text { Appeared clean. }\end{array}$ & $\begin{array}{l}\text { Swab sterile on } \\
\text { culture. }\end{array}$ & 8 & None. & $\begin{array}{l}\overrightarrow{0} \\
\overrightarrow{\vec{\omega}} \\
\text { బ }\end{array}$ \\
\hline 24 & $\begin{array}{l}\text { Compound } \\
\text { Femur. }\end{array}$ & $\begin{array}{l}\text { Through and through } \\
\text { wounds. 6" long outer } \\
\text { side. } 4^{\prime \prime} \text { long inner } \\
\text { side. Fairly clean. }\end{array}$ & $\begin{array}{l}\text { Staph. Aureus. } \\
\text { Ps. Pyocyaneus. } \\
\text { B. Proteus. }\end{array}$ & I8 & $\begin{array}{l}720,000 \\
\text { units. }\end{array}$ & $\begin{array}{l}35,000 \text { units } \\
\text { tube into wound }\end{array}$ \\
\hline 25 & $\begin{array}{l}\text { Compound Comminuted } \\
\text { Fracture Left Femur. }\end{array}$ & $\begin{array}{l}\text { Through and through } \\
\text { wound buttock to } \\
\text { outer thigh. Exit } \\
\text { wound 2" diameter. } \\
\text { Fairly clean. }\end{array}$ & $\begin{array}{l}\text { B. Coli. } \\
\text { B. Subtilis. }\end{array}$ & 7 & $\begin{array}{l}\text { I, I30,000 } \\
\text { units. }\end{array}$ & 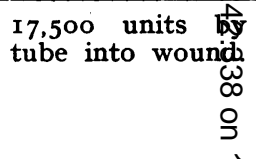 \\
\hline 26 & $\begin{array}{l}\text { Compound Comminuted } \\
\text { Fracture Right Humerus. }\end{array}$ & $\begin{array}{l}4^{\prime \prime} \text { long wound on } \\
\text { outer side of arm. } \\
\text { Appeared clean. }\end{array}$ & B. Subtilis. & 6 & $\begin{array}{l}862,000 \\
\text { units. }\end{array}$ & $\begin{array}{l}35,000 \text { units } \\
\text { tube into woung. }\end{array}$ \\
\hline 27 & $\begin{array}{l}\text { Compound Comminuted } \\
\text { Fracture Left Humerus. }\end{array}$ & $\begin{array}{l}\text { Small medial entry } \\
\text { wound. Large lateral } \\
\text { exit wound } 5^{\prime \prime} \times 3^{\prime \prime} \text {. }\end{array}$ & $\begin{array}{l}\text { Swab sterile on } \\
\text { culture. }\end{array}$ & 7 & $\begin{array}{l}982,500 \\
\text { units. }\end{array}$ & 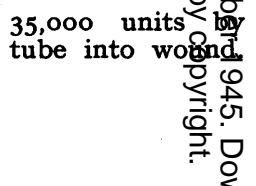 \\
\hline 28 & $\begin{array}{l}\text { Compound Comminuted } \\
\text { Fracture of Olecranon. }\end{array}$ & $\begin{array}{l}3^{\prime \prime} \text { lacerated wound } \\
\text { outer side of elbow. } \\
\text { Appeared clean. }\end{array}$ & Staph. Aureus. & 8 & None. & $\begin{array}{l}\text { 18,750 units } \\
\text { tube into woung }\end{array}$ \\
\hline 29 & $\begin{array}{ll}\text { Compound } & \text { Fracture } \\
\text { Right Femur. } & \end{array}$ & $\begin{array}{l}\text { Small posterior wound } \\
2^{\prime \prime} \text { diameter. Smaller } \\
\text { anterior wound } \overline{1}^{\prime \prime} \\
\text { diameter. } \\
\text { Appeared clean. }\end{array}$ & B. Coli. & 6 & $\begin{array}{l}980,000 \\
\text { units. }\end{array}$ & $\begin{array}{l}35,000 \text { units } \\
\text { tube into woungs. } \\
\end{array}$ \\
\hline 30 & $\begin{array}{l}\text { Compound } \quad \text { Fracture } \\
\text { Left Femur. }\end{array}$ & $\begin{array}{l}\text { Wound on outer side } \\
\text { and back of thigh } 3^{\prime \prime} \\
\text { diameter. } \\
\text { Appeared clean. }\end{array}$ & $\begin{array}{l}\text { Swab sterile on } \\
\text { culture. }\end{array}$ & 8 & $\begin{array}{l}\text { 700,000 } \\
\text { units. }\end{array}$ & $\begin{array}{l}32,500 \text { units 产 } \\
\text { tube into wound: }\end{array}$ \\
\hline
\end{tabular}

formed on clinical grounds alone, but a swab was taken at the time as a guide to future treatment. It so happened that when the swab results were returned clostridia were not present in any case. This is probably because wounds containing gasforming organisms are usually dirty and would not be considered fit on clinical grounds for suture. Staphylococcus Aureus, as is to be expected, was found frequently, and unfortunately, it was often in combination with Ps. Pyocyaneus and B. Proteus. Those few cases infected with S. Aureus alone were usually easily sterilised with penicillin and the wounds healed well. B. Subtilis waso found on five occasions, but was easily eliminated and did not appear to delay healing.

The systemic doses of penicillin varied con- $N$ siderably from over four million units in case No. IN downwards, but the average dose lay between 500,000 and $I, 000,000$ units. The reason for this was the very great difterence in the amounts given to some patients before their arrival at this hospital. The local dose of penicillin given by means of $a_{?}^{+}$ 
(continued)

\begin{tabular}{|c|c|c|c|}
\hline Chemo-Therapeutic Agents & $\begin{array}{l}\text { Condition of Wound } \\
\text { 14 Days after Suture }\end{array}$ & Comments & Result \\
\hline Course of Sulphamezathine. & $\begin{array}{l}\text { Wound clean and } \\
\text { healed. }\end{array}$ & $\begin{array}{l}\text { Local Penicillin alone overcame the infection } \\
\text { with Staph. Aureus in this case. B. Subtilis } \\
\text { did not delay healing. } \\
\text { No bone necrosis. }\end{array}$ & Good. \\
\hline $\begin{array}{l}\text { Course of Sulphanilamide. } \\
\text { Insufflation of Proflavine Sulpha- } \\
\text { thiazole powder at time of suture. }\end{array}$ & $\begin{array}{l}\text { Wound clean and } \\
\text { healed. }\end{array}$ & $\begin{array}{l}\text { Wound was sterile at time of operation. } \\
\text { Proflavine Sulphathiazole powder applied at } \\
\text { time of suture. No Penicillin. } \\
\text { No bone necrosis. }\end{array}$ & Good. \\
\hline $\begin{array}{l}\text { Course of Sulphamezathine. } \\
\text { Insufflation of Proflavine Sulpha- } \\
\text { thiazole powder at time of suture. }\end{array}$ & $\begin{array}{l}\text { Wound almost com-. } \\
\text { pletely healed. }\end{array}$ & $\begin{array}{l}\text { Healing impaired by Gram. negative pus. } \\
\text { Penoxetol is being used to eradicate Ps. Pyo- } \\
\text { cyaneus. } \\
\text { No bone necrosis. }\end{array}$ & Good. \\
\hline $\begin{array}{l}\text { Course of Sulphanilamide. } \\
\text { Insufflation of Proflavine Sulpha- } \\
\text { thiazole powder at time of suture. }\end{array}$ & $\begin{array}{l}\text { Wound clean and } \\
\text { healed. }\end{array}$ & Clean healing of wound with no bone necrosis. & Good. \\
\hline $\begin{array}{l}\text { Course of Sulphamezathine. } \\
\text { Insufflation of Proflavine Sulpha- } \\
\text { thiazole powder at time of suture. }\end{array}$ & $\begin{array}{l}\text { Sutured portion of } \\
\text { wound clean and healed. }\end{array}$ & $\begin{array}{l}\text { The large exit wound could not be completely } \\
\text { closed due to skin loss, but the fracture site } \\
\text { was completely cut off from the surface of the } \\
\text { wound, a small area of muscle being left ex- } \\
\text { posed. Remainder of wound healed in I } 4 \text { days. } \\
\text { No bone necrosis. }\end{array}$ & $\begin{array}{l}\text { Satis- } \\
\text { factory. }\end{array}$ \\
\hline Course of Sulphanilamide. & Wound soundly healed. & $\begin{array}{l}\text { Clean healing of wound. Wound sterile in } \\
\text { spite of delay of } 8 \text { days between infliction and } \\
\text { suture. } \\
\text { No bone necrosis. }\end{array}$ & Good. \\
\hline
\end{tabular}

tube into the wound, was seldom more than I00,000 units and frequently less than 50,000 units. The economy of the local method is therefore obvious, but I think it is agreed by most workers that when treating or attempting to prevent bone infection systemic administration is necessary. I endeavoured to combine the two methods with a view to obtaining the maximum effect with the minimum expenditure of penicillin. Now that penicillin is becoming more plentiful it is probable that in the future systemic administration will be the method of choice in view of the danger of gram-ve contamination when the local method is used.

A number of the cases were complicated by other injuries such as considerable soft tissue wounds, others had burns. One case, No. I8, had in addition to a compound fracture of the femur a perforating abdominal wound requiring resection. This delayed the closure of his leg wound to 20 days after injury, yet in spite of this it was sterile on culture, and healed without difficulty. Another 
point illustrated by a consideration of the failures is that most of them were fractures with an extreme degree of comminution and with a mixed infection. This type of wound can be readily distinguished on clinical grounds. Sequestrum formation in these circumstances is extremely probable and closure of the wound is best avoided. All the fractures are uniting or have united satisfactorily, even cases such as Nos. 7 and I3, which show very extensive comminution. It is noteworthy that there is only one example of a compound fracture of the tibia and fibula in the whole series, No. 22. This is because these fractures are usually accompanied by extensive skin loss which prevents closure of the wound. Various plastic procedures, such as rotation flaps and pedicle grafts, have had a considerable degree of success in these difficult cases, and this aspect of the problem is being further investigated (Jeffreys, personal communication).

\section{Conclusions}

The results obtained in this small series are encouraging, and are in accord with a number of other and considerably larger series published since this paper was written. It is very difficult, however, to assess the value of penicillin or other chemotherapeutic agents in the treatment of these cases as no strictly comparable series treated without these drugs was available. The number of cases is also too small for any accurate conclusions to be drawn, and it is presented as an indication of the way in which the problem of preventing bone infections in compound fractures might be tackled. Comparison with similar cases treated by secondary suture during the last war, but without penicillin or other chemotherapeutic drugs, would be interesting, but time and circumstances did not allow me to consult the literature.

The number of compound fractures which passed through the hospital during the period of this investigation was several hundred, and these cases form only a small portion selected at random of the total. The factors governing closure of these wounds were the extent of the skin loss and the presence of infection. In many cases extensive skin loss prevented secondary suture and this was found to be a factor of great importance. Regarding infection the decision to act on clinical impression of the wound was found to be sound. Those wounds which appeared clean clinically mostly did well, and obviously infected wounds usually broke down. Disappointment was experienced when an apparently clean wound broke down due to the presence of an organism not sensitive to penicillin. Gram-ve pus produced by Ps. Pyocyaneus and B. Proteus, B. Coli was encountered in a number of cases. It was usually responsible for the delay in healing in those cases

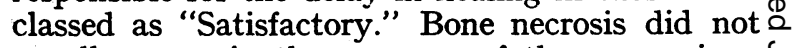
usually occur in the presence of these organisms $\stackrel{\leftarrow}{\leftarrow}$ unless some other pathogen, usually S. Aureus, $\underset{\vec{F}}{\vec{P}}$ was also present. Phenoxetol alone or in com- $-\overrightarrow{0}$ bination with penicillin might improve these cases, $\frac{C}{0}$ and this is being investigated at the present time. $\frac{\bar{\omega}}{\bar{N}}$

Penicillin, in infections which are susceptible to $\overrightarrow{\widetilde{D}}$ it, and other chemotherapeutic agents are un- $\varrho$ doubtedly of very great benefit, but it cannot be too strongly emphasised that the correct surgical $\overrightarrow{0}$ treatment of the wound is the essential to success. A late follow up of the cases was not possible $\vec{\omega}$ owing to the prevailing instructions to transfer $\frac{\sigma}{\sigma}$ patients to hospitals near their home, as they became ambulatory. At the time of leaving hospital all these fractures were uniting satis- $\rightarrow$ factorily and there were no cases of non-union. is All wounds which had healed remained so and? there were no cases of late breakdown of the wound. $\omega_{\infty}$

I should like to thank Sir Walter Haward, O.B.E., 의 Director General of the Ministry of Pensions, for per-mission to publish this paper. Dr. S. J. Scurlock, Medical $\square$ Superintendent of Ronkswood Hospital, for his encourage- $\mathbb{D}$ ment and advice, and Dr. Lawrence for the bacteriological work. My thanks are also due to my house surgeons; Dr. B. Cluley, Dr. L. Thrower, and Dr. Dencer, and ât the members of my surgical team for their help in the treatment of these cases. I am indebted to Mr. Brendw $\overrightarrow{0}$ Kerney for the X-ray reproductions and photograph, and to Miss Tysall and Miss Higginson for their help wi the patients' records.

\section{REFERENCES}

1. Medical Research Council, "An Investigation of the Therapeutic Properties of Penicillin," B.M. J., 1944, No. 4345, p. 513." 2. I. W. J. McADAM, J. P.' DUGUID, S. W. CHALLINOR, "'Systemic $\varrho$ Administration of Penicillin," Lancet, 1944, Vol. 12, p. 336. 3. J. GOUGH, H. BERRY, "Phenoxetal in Pyocynea Infections," Lancet, 1944, Vol. 2, p. 176.

\section{NOTES AND ANNOUNCEMENTS}

J. B. Lippincott Company will shortly be publishing the following:

\section{ESSENTIALS OF ALLERGY}

By LEO H. CRISP, M.D. 42 illustrations in black and white and I plate in full colour. PriceN 30s. net.

A concise, complete handbook designed as $a^{2}$ working manual for the practising physician and covering all aspects of classification, etiology, diagnosis, prognosis and treatment. Diagnosis and 